\title{
Philippines - Taxes on Distilled Spirits: Like Products and Market Definition
}

\author{
DAMIEN NEVEN * \\ Graduate Institute of International and Development Studies \\ JOEL P. TRACHTMAN** \\ Fletcher School of Law and Diplomacy, Tufts University
}

\begin{abstract}
This paper provides a legal-economic analysis of the Appellate Body decision in Philippines - Taxes on Distilled Spirits (Philippines-Spirits). In Philippines-Spirits, the Panel and the Appellate Body had an opportunity to consider again the scope of 'like products' and of 'directly competitive or substitutable products' under Article III:2 of GATT. The Panel and Appellate Body followed the Border Tax Adjustments factors in order to determine whether the products were sufficiently similar. The Appellate Body explicitly extended its jurisprudence from other areas of Article III to a like-products determination under the first sentence of Article III:2: this analysis is to be focused on the degree of competition between the imported and domestic products. We observe that the effect of different taxation on domestic products is affected by the degree of substitution between products as well as competitive conditions, whereas the Appellate Body seems to focus on the former and ignore the latter. We also question some of the Panel and Appellate Body interpretations of the evidence regarding the degree of substitution between products. Overall, we find that even if there may be a segment in which foreign and domestic products compete, the reported evidence in this case would seem to be consistent with the view that for the bulk of the market, foreign and domestic items are distant substitutes.

Putting aside the jurisprudence, a methodologically sound finding regarding substitution (and competition) seems necessary, but not sufficient, for a finding of inefficient discrimination. In order to find inefficient discrimination, there must also be a finding that the nonprotectionist benefits that may arise from the national regulation are not sufficient to justify the discriminatory action, otherwise, rational regulation that is globally efficient might be invalidated, inappropriately restricting the national right to regulate. In the present case, the Philippines articulated no nonprotectionist rationale for its distinctions. Existing WTO jurisprudence in this area prior to the Appellate Body decision in US-Clove Cigarettes (in the context of Article 2.1 of the technical barriers to trade agreement) has only hinted at the additional focus on the justificatory role of nonprotectionist regulatory benefits,
\end{abstract}

*Email: Damien.Neven@graduateinstitute.ch.

**Email: joel.trachtman@tufts.edu.

We would like to thank J. Wouters, P. Mavroidis, M. Ruta, K. Maskus, and participants in the June 2012 ALI workshop in Florence for useful comments on an earlier draft of this paper. 
yet an explicit and appropriately contextualized reference to the nonprotectionist rationale, if any, of regulation seems to be a necessary part of decision-making.

\section{Introduction and facts}

This appeal related to complaints brought by the European Union (EU) and the United States (US) against the Philippines, claiming that the Philippines's excise-tax regime applicable to distilled spirits was inconsistent with Article III:2 of the General Agreement on Tariffs and Trade 1994 (GATT, 1994). ${ }^{1}$ The EU and US claimed that the Philippines violated the national-treatment obligations contained in both the first sentence (First Sentence) and the second sentence (Second Sentence) of Article III:2, by applying different internal tax treatment to distilled spirits produced from certain 'designated raw materials' (sap of the nipa, coconut, cassava, camote, or buri palm, or from juice, syrup, or sugar of the cane), compared to the tax treatment applied to distilled spirits from 'non-designated raw materials' (everything else).

With respect to the US complaint, the Panel found violations of both the First Sentence and the Second Sentence. The Appellate Body confirmed these findings. With respect to the EU complaint, the Panel only examined consistency with the First Sentence, and found violations. The Appellate Body found that the Panel erred in treating the EU's Second Sentence claims as made in the alternative, and completed the analysis to find a violation of the Second Sentence in connection with the EU's claims.

It will be recalled that the First Sentence prohibits internal taxes on imported products in excess of internal taxes on like domestic products, while the Second Sentence, as elaborated by the related ad note, prohibits the application of dissimilar internal taxes on domestic products compared to those applied to directly competitive or substitutable imported products in a manner so as to afford protection to the domestic products. ${ }^{2}$ The Appellate Body has repeatedly stated that the object and purpose of Article III is 'to provide equality of competitive conditions for imported products in relation to domestic products'. ${ }^{3}$

The Philippines argued that its measures were not discriminatory in the sense of Article III:2 because its distinctions were not based on national origin, but on different raw materials. Indeed, this was a case of alleged de facto discrimination. In connection with the First Sentence claims, the Philippines argued that the Panel

1 Appellate Body Report, Philippines - Taxes on Distilled Spirits, WT/DS396/AB/R, WT/DS403/AB/R, adopted 20 January 2012 (hereafter Philippines-Spirits).

2 For an excellent legal and economic analysis of the jurisprudence in this area, see Henrik Horn and Petros C. Mavroidis (2004), 'Still Hazy after All These Years: The Interpretation of National Treatment in the GATT/WTO Case-law on Tax Discrimination', 15:1, European Journal of International Law, 39.

3 Appellate Body Report, Japan - Taxes on Alcoholic Beverages, WT/DS8/AB/R, WT/DS10/AB/R, WT/ DS11/AB/R, adopted 1 November 1996, p. 16 (citations omitted) (hereafter Japan-Alcoholic Beverages). 
erred in its interpretation and application of the term 'like products'. The Philippines argued that any significant physical difference would be sufficient to render two products unlike. ${ }^{4}$ The Panel disagreed, finding that sugar-based and non-sugar-based distilled spirits are 'like' despite numerous physical differences. So, the Appellate Body was required to determine whether the Panel erred in finding that each type of imported distilled spirit involved in this dispute made from nondesignated raw materials is 'like' the same type of domestic distilled spirit made from designated raw materials.

With respect to the Second Sentence claims, the Appellate Body was required to determine whether the Panel erred in finding that all the distilled spirits at issue, whether imported or domestic, and irrespective of the raw materials from which they were made, were 'directly competitive or substitutable' (DCOS) products.

All products at issue are distilled spirits of the following types: gin, brandy, rum, vodka, whisky, tequila, and tequila-flavoured spirits. The Panel found that all distilled spirits produced in the Philippines are made from designated raw materials (i.e., sugar), and based on ethyl alcohol processed in the Philippines or in other countries where sugar cane is produced commercially. Therefore, all distilled spirits produced in the Philippines were subject to a flat tax rate of 14.68 Philippine pesos per proof litre. On the other hand, 'the vast majority of' distilled spirits imported into the Philippines are processed from nondesignated raw materials, and are therefore subject to one of three tax rates, depending on their net retail price. These rates are $158.73,317.44$, and 634.90 pesos per proof litre. ${ }^{5}$

\section{Legal analysis}

The term 'discrimination' is not easily applied in all cases. We may 'know it when we see it', but it is useful to attempt to delineate the components of a finding of discrimination. This case focused on the interpretation and application of Article III:2. Article III:2 contains two prohibitions, designated as First Sentence and Second Sentence, and including the relevant ad note:

Article III:2. The products of the territory of any contracting party imported into the territory of any other contracting party shall not be subject, directly or indirectly, to internal taxes or other internal charges of any kind in excess of those applied, directly or indirectly, to like domestic products. Moreover, no contracting party shall otherwise apply internal taxes or other internal charges to imported or domestic products in a manner contrary to the principles set forth in paragraph $1 . *$

Ad note. A tax conforming to the requirements of the first sentence of paragraph 2 would be considered to be inconsistent with the provisions of the second

4 Appellate Body Report, Philippines-Spirits, para. 13. 5 Ibid., paras. 100-103. 
sentence only in cases where competition was involved between, on the one hand, the taxed product and, on the other hand, a directly competitive or substitutable product which was not similarly taxed.

Provided it is found that the national measure is an internal tax or other internal charge, the substantive questions in Article III: 2 discrimination cases are the following:

1. Product competition comparison. The threshold question is whether the relevant imported and domestic products are sufficiently in competition with one another to go on to the next step of considering whether the relevant national measure constitutes discrimination. This is by necessity a question of whether the relevant imported and domestic products are, or potentially can be, in the same market, and can only be answered by establishing first a threshold of competitiveness. Although the Appellate Body has repeatedly said that the product comparison is like an 'accordion' with different breadths in different contexts, ${ }^{6}$ it would assist predictability and consistency of decision-making to establish a uniform threshold of competitiveness for purposes of discrimination cases. The Appellate Body has held in the context of the Second Sentence and Article III:4, and in the present case has confirmed in the context of the First Sentence, that the determination of the 'likeness' or direct competition or substitutability (DCOS) of products is to be made by reference to an analysis of product competition. And yet, the Appellate Body has also repeatedly stated that it is reluctant to rely on quantitative analyses of competitive relationships. ${ }^{7}$

2. Treatment comparison. Assuming that there is sufficient competition, is the class of imported products subject to adverse treatment compared to the class of domestic products? Adverse treatment is defined in the Article III: 2 context as higher taxation (First Sentence) or dissimilar taxation (Second Sentence).

For First Sentence claims, the product competition comparison and the treatment comparison described above are necessary and sufficient to complete a case for violation. As the Appellate Body stated in Canada-Periodicals:

[T] here are two questions which need to be answered to determine whether there is a violation of Article III:2 of the GATT 1994: (a) whether imported and domestic products are like products; and (b) whether the imported products are taxed in excess of the domestic products. If the answers to both questions are affirmative, there is a violation of Article III:2, First Sentence. ${ }^{8}$

6 Japan-Alcoholic Beverages, at 21 ('The width of the accordion in any one of those [provisions] must be determined by the particular provision in which the term 'like' is encountered as well as by the context and the circumstances that prevail in any given case to which that provision may apply.')

7 Appellate Body Report, Korea-Taxes on Alcoholic Beverages, WT/DS75/AB/R, WT/DS84/AB/R, adopted 17 February 1999, para. 134 (hereafter Korea-Alcoholic Beverages).

8 Appellate Body Report, Canada-Certain Measures Concerning Periodicals, WT/DS31/AB/R, adopted 30 July 1997, pp. 22-23 (hereafter Canada-Periodicals). 
3. So as to afford protection. On the other hand, the Second Sentence includes a reference to 'the principles set forth in paragraph 1'. This has been interpreted to mean a reference to the language of Article III: 1 stating that domestic measures should not be applied 'so as to afford protection to domestic production' (SATAP). This language calls for an additional analytical step, which we address in detail below. In short, it focuses on the objective structure of the measure in order to infer whether it is designed so as to afford protection.

\subsection{Like products}

In Japan-Alcoholic Beverages, the Appellate Body found that the scope of 'like products' under the First Sentence is to be construed narrowly in order to avoid condemning too broad a class of governmental measures, because the First Sentence lacks the moderating consideration of SATAP. ${ }^{9}$

For the First Sentence claims, the critical question in Philippines-Spirits was whether the regulatory categories established under Philippines law-essentially the distinction between designated raw materials and nondesignated raw materials - would be accepted as providing distinct treatment to products that were not like products, or whether, instead, distilled spirits made with designated raw materials are like products by reference to distilled spirits made with nondesignated raw materials. So, the critical question was whether the imported and domestic products at issue were like products. The Panel found that "(i) all distilled spirits at issue in this dispute are "like products", whether imported or domestic, and irrespective of the raw materials from which they are made; and (ii) each type of imported distilled spirit at issue in this dispute made from nondesignated raw materials is "like" the same type of domestic distilled spirit made from designated raw materials'. ${ }^{10}$

The Appellate Body first examined the Panel's second finding. The Panel followed the Border Tax Adjustments ${ }^{11}$ factors, as developed in subsequent jurisprudence, examining (i) the products' properties, nature, and quality, that is their physical characteristics; (ii) the products' end uses in the Philippines; (iii) the Philippine consumers' tastes and habits; and (iv) the products' tariff classification. ${ }^{12}$ The Appellate Body also examined the relevant internal regulations of the Philippines. The Appellate Body pointed out that these criteria are not exhaustive, but are tools available for assessing the evidence relating to the competitive relationship between imported and domestic products in order to establish likeness. ${ }^{13}$

9 Japan-Alcoholic Beverages, pp. 19-20.

10 Appellate Body Report, Philippines-Spirits, para. 110.

11 Report of the Working Party, Border Tax Adjustments, L/3464, adopted 2 December 1970.

12 The original Border Tax Adjustments factors did not include tariff classification, but the Appellate Body confirmed that tariff classification is an additional criterion in Japan-Alcoholic Beverages, at 23.

13 Appellate Body Report, Philippines-Spirits, para. 131. 
The Appellate Body thus extended its earlier jurisprudence in which it had already found that the like-products analysis and DCOS analysis is based on an analysis of the competitive relationship between the imported and domestic products in the context of Article III: $4^{14}$ and in the context of the Second Sentence, respectively. ${ }^{15}$

But if the Border Tax Adjustment factors are simply tools, under what circumstances should a Panel or the Appellate Body adopt a different set of tools, which might be superior? The Appellate Body noted that 'a panel examines these criteria in order to make a determination about the nature and extent of a competitive relationship between and among the products'. ${ }^{16}$ As discussed below, the set of factors examined in traditional Article III product comparisons seems less sophisticated, less precise, and less plausible than a modern economic analysis of the extent of competition between two products, which is essentially the question of the definition of the relevant market in which they compete.

And yet in Korea-Alcoholic Beverages, the Appellate Body approved the Panel's finding that 'if a particular degree of competition had to be shown in quantitative terms, that would be similar to requiring proof that a tax measure has a particular impact on trade'. ${ }^{17}$ The Panel in that case was concerned that 'if a certain degree of competition must be shown, it is similar to showing that a certain amount of damage was done to that competitive relationship by the tax policies in question'. ${ }^{18}$ In the Japan-Alcohol case, the Appellate Body had held that no proof of trade effects is required. However, while showing competition in quantitative terms is a necessary predicate to showing trade effects arising from the tax policies in question, the Panel's logic is incorrect because an additional step is required to move from identifying the degree of competition to establishing the effects of the national measure on competition. Nor is it necessarily correct, at least from an economic standpoint, that showing trade effects should not be part of the Article III analysis. We agree with Robert Hudec that any tribunal considering discrimination in the trade context will inevitably be influenced by the aim and effects of the relevant measure. ${ }^{19}$ If Hudec's insight is correct, it would be best to make the parameters for these assessments explicit.

14 Appellate Body Report, European Communities-Measures Affecting Asbestos and Asbestos Containing Products, WT/DS135/AB/R, adopted 5 April 2001 (hereafter EC-Asbestos).

15 Korea-Alcoholic Beverages.

16 Appellate Body Report, Philippines-Spirits, para. 119, citing EC-Asbestos.

17 Appellate Body Report, Korea-Alcoholic Beverages, paras. 130-131.

18 Panel Report, Korea-Taxes on Alcoholic Beverages, WT/DS75/R, WT/DS84/R, adopted 17 February 1999, as modified by Appellate Body Report WT/DS75/AB/R, WT/DS84/AB/R, para. 10.42.

19 Robert E. Hudec (1998), 'GATT/WTO Constraints on National Regulation: Requiem for an “Aim and Effects" Test', 32:3 The International Lawyer 619, 620 [hereafter 'Aim and Effects']; reprinted in R. E. Hudec (1999), Essays on the Nature of International Trade Law, London: Cameron May, at 359395, and at http://www.worldtradelaw.net/articles/hudecrequiem.pdf (last visited 25 July 2012). See also Amelia Porges and Joel P. Trachtman (2003), 'Robert Hudec and Domestic Regulation: The Resurrection of Aim and Effects', 37:4, Journal of World Trade, 783-799. 
No claims were raised on appeal regarding the Panel's finding that the imported and domestic products share the same end uses..$^{20}$ As to physical characteristics, the Philippines argued that 'like products' under the First Sentence is limited to 'identical products'. According to the Philippines, any significant difference in physical characteristics would be sufficient to render the products unlike. ${ }^{21}$ This position would certainly limit the scope of application of the First Sentence. However, the Appellate Body disagreed, finding that the simple fact of different raw materials need not have been viewed as disqualifying the imported and domestic spirits from being considered 'like'. ${ }^{22}$ Perhaps if the difference in physical characteristics had a nonprotectionist regulatory implication, as the difference between asbestos and fibreglass components of insulation had in the EC-Asbestos case, the Appellate Body would have found a way to distinguish the products.

The Appellate Body then turned to the Philippines's argument that because differences in chemical composition resulted in different taste, flavour, and aroma, the imported and domestic spirits were not like. The Panel had found that for each type of distilled spirit - gin, brandy, vodka, whisky, tequila, and tequila-flavoured spirits - there was similarity in physical characteristics despite the differences in raw materials. The Appellate Body accepted the Panel's determination, considering that 'if differences in raw materials leave fundamentally unchanged the competitive relationship among the final products, the existence of these differences would not necessarily negate a finding of "likeness",.23 The production process for the Philippines domestic spirits was designed to ensure that the final product is as close as possible in organoleptic properties to the imported products made from raw materials that are more traditional. Again, the Appellate Body examines these factors as qualitative determinants of a competitive relationship, leaving open the question of how the Appellate Body would handle a circumstance in which the competitive relationship is not affected by the differences, but where the differences result in a consumption externality or production externality that government determines to address through regulation.

The next of the Border Tax Adjustments factors addressed by the Appellate Body was consumer tastes and habits. The Panel had found what it called a significant degree of competitiveness or substitutability between domestic and imported distilled spirits in the Philippine market. ${ }^{24}$ It based its conclusions on two reports on substitutability in consumer preferences by Euromonitor International and by M. J. Abrenica and J. Ducanes (the 'substitutability studies'). ${ }^{25}$ 'The Panel

20 Appellate Body Report, Philippines-Spirits, para. 113.

21 Ibid., para. 115.

22 Ibid., para. 122.

23 Ibid., para. 125.

24 Panel Report, Philippines-Spirits, para. 7.62.

25 Euromonitor International, 'Consumer Perceptions Regarding Substitutability in the Philippines Distilled Spirits Market' (August 2010) (submitted by complainants); and M. J. Abrenica and J. Ducanes, 
considered that both substitutability studies suggest that a simultaneous increase in the price of domestic Philippine distilled spirits and decrease in the price of imported distilled spirits, such as that which would result from an equalization in the respective levels of the excise tax, could result in the substitution of the consumption of domestic distilled spirits for imported distilled spirits in the Philippine market.'26

The Appellate Body observed that the degree of competition and substitutability that is required under the First Sentence must be higher than that under the Second Sentence. It referred to its finding in Canada-Periodicals that a relationship of 'imperfect substitutability' would still be consistent with DCOS under the Second Sentence, but that a relationship of perfect substitutability would fall under the First Sentence. ${ }^{27}$ However, the Appellate Body in the present case observed that perfect substitutability is not required for First Sentence cases: 'products that are close to perfectly substitutable can be "like products", ${ }^{28}$ Furthermore, the Appellate Body found that the fact that domestic and imported distilled spirits in the Philippines do not share all channels of distribution does not establish that they are not like products. ${ }^{29}$ Therefore, the Appellate Body did not consider that the Panel erred in determining that the products at issue were like products.

The Philippines had also claimed that the Panel acted inconsistently with Article 11 of the DSU by concluding that there was no evidence of the existence of two separate markets, based on price, in the Philippines. 'The Panel found that "a large proportion of the Philippine population has a limited ability to purchase distilled spirits beyond certain price levels", but that the market is not divided into two segments.' 30 The Appellate Body found that the Panel had taken into account the evidence submitted by the Philippines, but had appreciated it differently.

The third factor addressed by the Appellate Body in determining whether the imported and domestic spirits were like products was tariff classification. The Panel found that all of the distilled spirits at issue in this case fall under Harmonized System (HS) heading 2208, and that the HS six-digit subheadings for gin and vodka make no distinction between distilled spirits on the basis of their raw materials. On the other hand, the six-digit subheadings for brandy and whisky refer to nonsugar raw materials. Thus, for the Panel, the six-digit subheadings did not offer conclusive guidance. ${ }^{31}$ The Appellate Body recalled that in Japan-Alcoholic Beverages, it found that tariff classification could be a helpful indicator of similarity only if

\footnotetext{
'On Substitutability Between Imported and Local Distilled Spirits' (University of Philippines School of Economics Foundation, 10 October 2010) (submitted by the Philippines).

26 Appellate Body Report, Philippines-Spirits, para. 146, citing Panel Report, para. 7.57.

27 Ibid., para. 148, citing Canada-Periodicals.

28 Ibid., para. 149.

29 Ibid., para. 153.

30 Ibid., para. 156, quoting Panel Report, Philippines-Spirits, para. 7.59.

31 Panel Report, Philippines-Spirits, para. 7.71.
} 
sufficiently detailed. The Appellate Body disagreed with the Panel, finding that these six-digit subheadings, including their explanatory notes, 'would not suggest that domestic brandies and whiskies made from designated raw materials are "like" imported brandies and whiskies made from non-designated raw materials'. ${ }^{32}$ However, since tariff classification is only one of the relevant criteria, the Appellate Body did not find that this is an error that rises to the level of a failure by the Panel to comply with its duties under Article 11 of the DSU. ${ }^{33}$

The Philippines argued that the Panel should have considered that the internal regulatory regimes of the EU and the US that prohibit the marketing of whisky and brandy made from sugar as brandy or whisky provided evidence that these were not like products. However, the Appellate Body found that the like-products determination is a market-by-market determination, and that the market to be evaluated in this case is the Philippines market, in which regulation does not make these distinctions. ${ }^{34}$

Consequently, the Appellate Body upheld the Panel's finding that, by imposing on each type of imported distilled spirit at issue in this dispute, because it was not made from designated raw materials, internal taxes in excess of those applied to like domestic distilled spirits of the same types, the Philippines violated the requirements of the First Sentence. ${ }^{35}$

Although the relevant language was not clear, the Panel seemed to add that all distilled spirits at issue in the current dispute were like products. In response, the Appellate Body held that 'to the extent that the Panel found, in paragraph 7.77 of its Reports, that all distilled spirits at issue in this dispute, regardless of the different types, are "like products" within the meaning of Article III:2, first sentence, of the GATT 1994, we disagree with this finding by the Panel'. ${ }^{36}$ In connection with its analysis, the Appellate Body stated that 'we do not consider that a significant degree of competitiveness or substitutability would support a finding of "likeness", 37 Thus, a finding of likeness requires a degree of competition that is higher than merely significant.

What do we learn about the definition of 'like products' from this decision? The Appellate Body has elaborated its jurisprudence further, but has not given great guidance from which states may anticipate which products will be 'like' and which will not. Physical differences alone are insufficient to make products 'unlike'. Products 'close to' perfectly substitutable are 'like'. More than a 'significant' degree of competitiveness or substitutability is needed. So, as states formulate taxation,

32 Appellate Body Report, Philippines-Spirits, para. 163.

33 Ibid., para. 164.

34 Ibid., paras. 167-168.

35 Ibid., para. 174.

36 Ibid., para. 179 (emphasis in original).

37 Ibid., para. 181 (emphasis in original). 
they will have difficulty anticipating whether the categories they establish will withstand WTO scrutiny.

Is it possible to add greater precision? We would conjecture that it is not, so long as nonprotectionist regulatory purpose cannot be considered independently. That is, by reserving to Panels and to itself great discretion to determine 'likeness', the Appellate Body retains room for judgment that can be used to determine products that are in competition with one another to be unlike, where the national regulatory distinction at issue serves a sufficiently significant nonprotectionist purpose. If, alternatively, the nonprotectionist regulatory purpose were considered elsewhere in the analysis - for example in the analysis of SATAP - then the determination of likeness in competitive terms could be made more precise and predictable. Of course, however, SATAP is not currently a relevant analysis under First Sentence claims.

\subsection{Directly competitive or substitutable products}

The Philippines also appealed the Panel's finding that the relevant products were DCOS, and that the tax was applied 'so as to afford protection'. It will be recalled that this Second Sentence analysis is understood as a 'cumulative' obligation; even if a national tax meets the requirements of the First Sentence, it must also meet the requirements of the Second Sentence.

In Japan-Alcoholic Beverages, the Appellate Body confirmed that it is appropriate to examine competition in the relevant markets, including cross-price elasticity of demand, as one factor, in addition to the Border Tax Adjustment factors, in determining DCOS. ${ }^{38}$

In Philippines-Spirits, 'the Panel rejected the Philippines' argument that the price gap between imported and domestic spirits, combined with the income disparity in the Philippines, demonstrates the existence of two distinct segments in the Philippine distilled spirits market'. ${ }^{39}$ The Appellate Body agreed with the Philippines that evidence of major price differentials could indicate that imported and domestic products are in separate markets. However, the Panel did not perform a complete analysis to determine the scope of the market. Nevertheless, the Panel found sufficient overlap in prices, and sufficient variation in purchasing power, to demonstrate instances of actual competition that suggest that imported and domestic distilled spirits are 'capable of being directly competitive or substitutable in the future'. ${ }^{40}$ On this basis, the Panel found a direct competitive relationship between domestic and imported distilled spirits.

38 Japan-Alcoholic Beverages, at 25.

39 Appellate Body Report, Philippines-Spirits, para. 197, citing Panel Report, Philippines-Spirits, para. 7.118.

40 Panel Report, Philippines-Spirits, para. 7.121 (emphasis in original). 
It is important that the Panel based its views on the capability of future competition, ${ }^{41}$ and that the Appellate Body accepted this in the present case and in earlier cases. So, it is not just a test of actual competition, but of potential competition. But the textual basis for this extension is uncertain: the text of the ad note to Article III refers to 'directly competitive or substitutable', not to capability of being 'directly competitive or substitutable'. Yet the Appellate Body's focus since Japan-Alcoholic Beverages seems to be on potential competition but for the challenged national measure, rather than a broader analysis.

In Philippines-Spirits, the Philippines argued that the Panel erroneously focused on the nature and quality of competition between the relevant imported and domestic products, rather than on the degree of competition. The Philippines cited the Appellate Body's decisions in Korea-Alcoholic Beverages ${ }^{42}$ and in US-Cotton $\mathrm{Yarn}^{43}$ in support of the argument that the correct analysis focuses on the degree of competition. In Korea-Alcoholic Beverages, the Appellate Body held that imported and domestic products are DCOS when they are 'in competition' in the marketplace. ${ }^{44}$ It further held that the term 'directly' suggests 'a degree of proximity in the competitive relationship between the domestic and the imported products'. ${ }^{45}$

However, in Philippines-Spirits, the Panel stated that 'the question before us under Article III of the GATT 1994 is not so much what the "degree of competition" between the products at issue is, but what is the "nature" or "quality" of their "competitive relationship"'.46 In a sense, this is a correct statement of what the Panels and Appellate Body actually do, because they do not seek to quantify the degree of competition.

Nevertheless, the Appellate Body found that the Panel 'appropriately ascertained the extent of the competitive relationship between imported and domestic distilled spirits in the Philippine market'. ${ }^{47}$ The Panel found that the Substitutability Studies indicate that there is 'a significant degree of competitiveness or substitutability' in the Philippine market between the imported and domestic distilled spirits at issue. $^{48}$

So, in both Philippines-Spirits and in Korea-Alcoholic Beverages, the Appellate Body has demanded a sufficient degree of competitiveness. However, the Appellate Body has insisted that this is broadly a qualitative, not a quantitative exercise,

41 Ibid., para. 7.100, citing Korea-Alcoholic Beverages, para. 114; United States-Transitional Safeguard Measure on Combed Cotton Yarn from Pakistan, WT/DS192/AB/R, adopted 5 November 2001, para. 91 (hereafter US-Cotton Yarn).

42 Appellate Body Report, Philippines-Spirits, para. 201, citing Philippines' appellant's submission, para. 88, citing Korea-Alcoholic Beverages.

43 Ibid., citing US-Cotton Yarn.

44 Appellate Body Report, Korea-Alcoholic Beverages, para. 114.

45 Ibid., para. 116.

46 Panel Report, Philippines-Spirits, para. 7.101.

47 Appellate Body Report, Philippines-Spirits, para. 204.

48 Panel Report, Philippines-Spirits, para. 7.113. 
although it can take some quantitative data relating to cross-price elasticity of demand into account. In the course of approving the Panel's focus on the 'nature and quality' of competition, while examining as part of its analysis the degree of competition, the Appellate Body in Philippines-Spirits reiterated its antipathy to quantitative analysis: 'In Korea-Alcoholic Beverages, the Appellate Body expressly found that a particular degree of competition need not be shown in quantitative terms, and cautioned panels against placing undue reliance on "quantitative analysis of the competitive relationship", because cross-price elasticity is not "the decisive criterion" in determining whether two products are directly competitive or substitutable. ${ }^{49}$ As discussed below, most economists would wonder what other criteria are relevant, while accepting that it would be inappropriate to find products not competitive where the alleged discriminatory measure is the basis for a price differential that suppresses competition.

In addition, the Philippines appealed on the basis of an argument that the Panel "erred in finding direct competition on the basis of a "non-representative" segment of its population having "access" to both types of spirits "at least on special occasions", ${ }^{50}$ Note that this is an argument about the definition of the relevant market for purposes of a finding of discrimination. However, the Appellate Body found that the Panel's finding of price overlap both for high- and low-priced distilled spirits supported the Panel's determination that the market is not segmented. ${ }^{51}$ Furthermore, the Appellate Body found that instances of actual competition are also highly probative in relation to potential competition' ${ }^{52}$

Finally, the Philippines claimed that the Panel failed to comply with the requirement under Article 11 of the DSU because it failed to make an objective assessment of the facts in its examination of the substitutability studies. The Euromonitor International survey had not estimated cross-price elasticity of demand, but had estimated that 'in a tax-neutral environment the market share of imported distilled spirits would increase by between $13 \%$ and $24.5 \%$, 53 On the other hand, the Abrenica and Ducanes study estimated cross-price elasticity of demand for imported and domestic spirits to range between -0.01 and 0.07 , considered by the authors to be 'low'. The Appellate Body considered that the weight and significance to be attributed to that estimated cross-price elasticity coefficient falls within the Panel's discretion as trier of facts. ${ }^{54}$ It also found important support for the Panel's finding in the Euromonitor International survey, which showed a significant degree of substitutability. It therefore found sufficient support for the Panel's appreciation

49 Appellate Body Report, Philippines-Spirits, para. 207, citing Appellate Body Report, KoreaAlcoholic Beverages, paras. 130, 131, 134.

50 Appellate Body Report, Philippines-Spirits, para. 213.

51 Ibid., para. 215.

52 Ibid., paras. 226, 228.

53 Ibid., para. 232.

54 Ibid., para. 236. 
of this evidence to the effect that 'the studies support the proposition that there is a significant degree of competitiveness or substitutability'. ${ }^{55}$

\subsection{So as to afford protection (SATAP)}

The First Sentence does not specifically refer to the principles of Article III:1, including the seemingly nonmandatory language to the effect that domestic measures 'should not be applied to imported or domestic products so as to afford protection to domestic production'. Therefore, the Appellate Body in JapanAlcoholic Beverages found that the First Sentence criteria of 'like products' and 'higher tax' are sufficient, in and of themselves, to instantiate the principles of Article III:1, without a separate analysis of whether the measures are applied 'so as to afford protection'. However, because the Second Sentence specifically invokes these principles, a separate finding of SATAP is required. ${ }^{56}$

Grammatically, 'so as to afford protection' could be understood to direct attention to either of two things: (i) the intent of the measure, or (ii) the effect of the measure. In Japan-Alcoholic Beverages, the Appellate Body stated that SATAP is not an issue of subjective intent: a Panel is not required to examine evidence of the actual legislative or regulatory intent. ${ }^{57}$ Rather, the Appellate Body in that case referred to the 1987 GATT Panel Report in an earlier iteration of that dispute, and made the following statement:

As in that case, we believe that an examination in any case of whether dissimilar taxation has been applied so as to afford protection requires a comprehensive and objective analysis of the structure and application of the measure in question on domestic as compared to imported products. We believe it is possible to examine objectively the underlying criteria used in a particular tax measure, its structure, and its overall application to ascertain whether it is applied in a way that affords protection to domestic products. ${ }^{58}$

So, it is not subjective aim that is to be evaluated, but an objective analysis of the structure of the measure is required in order to infer a protective aim.

The injunction against examination of subjective intent has not been followed consistently. In Canada-Periodicals, the Appellate Body stated that it was following Japan-Alcoholic Beverages in applying the SATAP component of the Second Sentence analysis. It nevertheless proceeded to refer to legislative documents and government statements indicating the 'objective and structure' of the tax in question. ${ }^{59}$ Canada-Periodicals thus confirms that the Appellate Body can

55 Panel Report, Philippines-Spirits, para. 7.113.

56 Japan-Alcoholic Beverages, at 18-19.

57 Ibid., at $27-28$.

58 Ibid., at 29.

59 Canada-Periodicals, at 27-28. 
consider both objective and subjective evidence of aims, in connection with the SATAP criterion.

The Philippines alleged that the Panel also erred in its finding that dissimilar taxation of the imported and domestic distilled spirits at issue was applied 'so as to afford protection' to Philippine distilled spirits. The Panel had rejected the argument made by the Philippines that its tax had no effect on competitive conditions because of the combined effect of (i) the low purchasing power of the Philippine population, and (ii) the pre-tax price differences between domestic and imported products. The Panel stated that the Appellate Body had rejected a similar argument in Korea-Alcoholic Beverages, because the earlier-stage finding that the products are directly competitive or substitutable precludes a finding of no competitive effect. ${ }^{60}$ Interestingly, the Appellate Body agreed with the Panel that 'the assessment of whether the excise tax could affect the competitive relationship between domestic and imported distilled spirits in the Philippine market pertains to the prong of analysis directed at determining whether the products are [DCOS]'. ${ }^{61}$

In the Korea-Alcoholic Beverages case, the Appellate Body had already clarified that SATAP is not concerned with trade volumes, or a particular trade effect, but is concerned with the conditions of competition. ${ }^{62}$ The Appellate Body in Philippines-Spirits quoted the Appellate Body's language in the Korea-Alcoholic Beverages case: 'it is ... not incumbent on a complaining party to prove that tax measures are capable of producing any particular trade effect'. ${ }^{63}$

So, according to the Panel and Appellate Body, there is no need to determine the capability of the different taxation to cause trade effects in connection with the SATAP analysis, as this is already included in the DCOS analysis. However, the Panel and Appellate Body are inappropriately combining two analyses: (i) whether the imported and domestic products are sufficiently in competition with one another, and (ii) whether and to what extent the tax at issue is capable of causing or causes trade effects. Perhaps the Panel and Appellate Body assume that any differential tax, applied to goods sufficiently in competition, causes actionable trade effects, or perhaps they believe that discrimination can be found without a finding of trade effects.

So, the remaining meaning of SATAP has to do with an objective assessment of design or intent. In Philippines-Spirits, 'the Panel reviewed "the design, architecture and structure" of the measure in some detail and observed that, while "[a]ll designated raw materials are grown in the Philippines and all domestic distilled spirits are produced from designated raw materials", the vast majority of imported

60 Appellate Body Report, Philippines-Spirits, para. 246.

61 Ibid., para. 256.

62 Korea-Alcoholic Beverages, paras. 119, 153.

63 Appellate Body Report, Philippines-Spirits, quoting Korea-Alcoholic Beverages, para. 153. 
distilled spirits "are not made from designated raw materials"' ${ }^{64}$ From this, the Panel drew the inference that the Philippines' tax system operated SATAP.

In Chile-Alcoholic Beverages, the Appellate Body stressed that the SATAP analysis is completely separate and additional to a finding of dissimilar taxation. ${ }^{65}$ This emphasis, and separation, foreshadowed the Appellate Body's approach to the issue of 'less favourable treatment' under Article III:4 in paragraph 100 of ECAsbestos. The Appellate Body referred again to the Japan-Alcoholic Beverages decision to the effect that the evaluation must consider objectively the structure of the national measure.

In Chile-Alcoholic Beverages, the Appellate Body evaluated the actual incidence of the tax, and found that the design of the tax coincidentally causes it to fall most heavily on imported goods, with imported goods falling largely into the high-tax category. ${ }^{66}$ The Panel had found that the structure of the Chilean alcohol tax did not relate to the purposes stated by Chile, and found that this lack of correlation - lack of 'suitability' - confirmed its finding that the Chilean measure was applied SATAP. On appeal, Chile argued that the Panel was wrong to inquire as to the purposes of the regulation. However, the Appellate Body approved this inquiry, stating that a measure's purposes are 'intensely pertinent' to the question of whether the measure is applied SATAP. This is because a plausible purpose - in the Appellate Body's words a 'countervailing explanation' 67 - might have helped to 'explain' a tax structure that otherwise appears to be applied so as to afford protection. So, again, aim may be relevant to a determination of SATAP.

SATAP has also emerged in Article III:4 jurisprudence, despite the lack of any specific invocation of Article III:1. After establishing a 'competitive likeness' test under Article III:4, the Appellate Body in the EC-Asbestos decision made clear that formal differences in the treatment of like products are not sufficient to make out a violation of Article III:4. There must also exist 'less favourable treatment'. 'The term "less favourable treatment" expresses the general principle, in Article III:1, that internal regulations "should not be applied... so as to afford protection to domestic production". ${ }^{68}$

In EC-Asbestos, the Appellate Body states that 'a Member may draw distinctions between products which have been found to be "like", without, for this reason alone, according to the group of "like" imported products "less favourable treatment" than that accorded to the group of "like" domestic products'. ${ }^{69}$

64 Appellate Body Report, Philippines-Spirits, para. 255, quoting Panel Report, Philippines-Spirits, para. 7.182 (emphasis in Panel Report).

65 Appellate Body Report, Chile - Taxes on Alcoholic Beverages, WT/DS87/AB/R, WT/DS110/AB/R, adopted 12 January 2000, para. 55 (hereafter Chile-Alcoholic Beverages).

66 Ibid., para. 66.

67 Ibid., para. 71.

68 EC-Asbestos, para. 100.

69 Ibid. 
The willingness to examine the class of imported products compared to the class of domestic products (presaged in Chile-Alcoholic Beverages), as opposed to examining the best treatment accorded to any domestic like product compared to the worst treatment accorded to any imported like products, is critical. Under Asbestos, different treatment alone-based on regulatory categories that distinguish between otherwise like products - is neither sufficient nor necessary to prove less favourable treatment. The Appellate Body seems to expect a substantive additional test to be applied under the rubric of 'less favourable treatment'.

It seems clear that SATAP would not be considered under the First Sentence. Although we do not know the precise relationship between 'like products' under the First Sentence and 'like products' under Article III:4, it seems safe under $E C-$ Asbestos to say that the former is narrower. Thus, if 'like products' under the First Sentence is understood as dealing with products that are more or less identical, including features that implicate regulation, perhaps there is no need for a SATAP analysis under the First Sentence. Of course, the First Sentence does not have an explicit textual locus for this determination. Perhaps this would be a reason to have a more constrained definition of 'like products' in connection with the First Sentence. ${ }^{70}$

2.4 An Interpretative argument for interpreting 'like' and 'DCOS' utilizing modern economic tools, and for interpreting 'like' narrowly to include only products that raise the same regulatory concerns

The Border Tax Adjustment factors are precedent, not treaty language. And of course, precedent is not formally binding in WTO law. As the Appellate Body points out, the Border Tax Adjustment factors are tools available to tribunals 'for organizing and assessing evidence relating to the competitive relationship between and among the products'. ${ }^{71}$ Below, we propose tools commonly regarded as superior in the economics profession. Of course, the interpretive task of a WTO Panel or the Appellate Body is not to determine what the economics profession believes, but if the member states of the WTO utilize a concept, such as competition, it appears that tribunals should use the best tools available to determine competition.

Under Article 3.2 of the WTO Dispute Settlement Understanding, Panels and the Appellate Body are to utilize the customary rules of interpretation of public international law. In Japan-Alcoholic Beverages, the Appellate Body confirmed that Articles 31 and 32 of the Vienna Convention on the Law of Treaties are included in these customary rules of interpretation. Article 31 requires that 'A treaty shall be interpreted in good faith in accordance with the ordinary meaning to

70 See Japan-Alcoholic Beverages, at 19-20 (definition of 'like products' for purposes of Article III:2 (first sentence) should be construed narrowly); Aim and Effects, supra note 19.

71 Appellate Body Report, Philippines-Spirits, para. 131. 
be given to the terms of the treaty in their context and in the light of its object and purpose.' Just as the Appellate Body found in US-Shrimp that the definition of 'natural resources' in Article $\mathrm{XX}(\mathrm{g})$ of GATT is not 'static' in its content or reference but is rather 'by definition, evolutionary', we might also argue that our understanding of like products and DCOS products may evolve as more reliable and plausible tools are developed by economics. Of course, it is necessary to remain faithful to the overall purpose of the clause interpreted. However, if, as the Appellate Body has consistently asserted, the meaning of these clauses is found in a search for a competitive relationship, it is worth recognizing that our understanding of competitive relationships has grown more reliable and plausible. Why should WTO law not take advantage of this evolution in understanding?

As expressed above, a test for discrimination that only refers to a competitionbased product comparison, and a treatment comparison that is inhospitable to nonprotectionist regulatory reasons for differential treatment, would invalidate appropriate and efficient regulation. There appears to be room in SATAP under the Second Sentence, and in 'less favourable treatment' under Article III:4, to include the question of nonprotectionist regulatory rationales for differential treatment. Already in Japan-Alcoholic Beverages, the Appellate Body expressed its concern that the First Sentence might excessively invalidate appropriate national measures:

Because the second sentence of Article III: 2 provides for a separate and distinctive consideration of the protective aspect of a measure in examining its application to a broader category of products that are not 'like products' as contemplated by the first sentence, we agree with the panel that the first sentence of Article III:2 must be construed narrowly so as not to condemn measures that its strict terms are not means to condemn. ${ }^{72}$

This concern might lead to an understanding of 'like' for purposes of First Sentence cases as requiring imported and domestic products to be so similar as not to raise different degrees of challenge to nonprotectionist regulatory goals.

This concern arises despite the continued availability of exceptions under Article XX. First, under Article XX the burden of proof is broadly on the respondent, and, second, not all regulatory purposes are included in the list of regulatory purposes in Article XX. Therefore, Article III must avoid invalidating good-faith regulatory distinctions.

\section{Economic analysis}

The objective of this section is two-fold. First, we will discuss the factors that may be relevant to an empirical assessment of the effect of discriminatory treatment. Second, we will briefly review from an economic standpoint how the Panel and Appellate Body have dealt with the evidence that relates to those factors.

72 Japan-Alcoholic Beverages, at 21. 


\subsection{Assessing discriminatory treatment}

In this section, we assume that Article III is concerned with the effect that different taxes on domestic and imported products may have. As discussed above, the Appellate Body has denied that Article III is concerned with effects, emphasizing instead the protection of competitive opportunities. However, we find it hard to give meaning to the protection of competitive opportunities in the absence of the effect that differential taxation may have either under current and/or future demand conditions. Even if the concept of competitive opportunities is understood in terms of an option for foreign producers to sell in the domestic market that is denied by the differential tax, such an option will only be valuable if indeed the differential tax is expected to have an effect on their sales.

As discussed in Neven (2001), ${ }^{73}$ the effect of different taxes on different products is formally identical to the effect of a relative increase in the marginal cost of some product. That is, a higher tax on one product can be seen as an increase in the marginal cost of that product. As a result of an increase in the marginal cost of one product (say the imported product), its price but also the prices of the other products (whose marginal cost are kept constant, say the domestic products) will increase.

As one would expect, the extent to which the increase in marginal cost will be passed through to consumers in the prices of both products will be affected by the degree of substitutability between the two products. Other things being equal, the greater the substitutability between the foreign and domestic products, the larger will be the pass-through on both products. ${ }^{74}$ With strong substitution, margins will be slim and firms will not be in a position to absorb an increase in cost by a reduction in margins. That is also to say that if foreign and domestic products are close substitutes, the protection granted to domestic firms increases (as measured by the increase in price that they can sustain). One can also easily check ${ }^{75}$ that the sales of the foreign firm (as measured by quantities) will fall, so that, in this particular sense, demand is shifted away from foreign firms. The degree of substitution can in turn be captured for instance by the cross-price derivative of demand (more on this later).

However, the degree of product differentiation (as a synonym for the degree of substitution) is not the only factor that will determine the extent to which domestic firms will be protected and demand will be foreclosed from foreign firms. As shown

73 Damien Neven (2001), 'How Should 'Protection' be Evaluated in Article III GATT Disputes?', 17 European Journal of Political Economy, 421.

74 The framework used in Neven (2001) assumes symmetric product differentiation among domestic firms and foreign firms. In that framework, a foreign firm is identified by its greater level of cost. A richer model would allow for a different level of product differentiation among domestic firms and between domestic and foreign firms. The effect of domestic competition on the level of protection would also obtain in that framework.

75 Ibid. 
in Neven (2001), the degree of rivalry in the domestic markets (as measured for instance by the number of firms) also matters. The less intense competition is in the domestic market (the lower the number of domestic competitors), the greater will be the pass-through to domestic and foreign prices. The pass-through (and hence the protection) will be greatest with a domestic monopoly and least when the domestic market is competitive (assuming that the degree of differentiation between domestic products is less than the differentiation between domestic and foreign products). This arises because a domestic monopolist will take advantage of a price increase by its foreign competitors and will find it attractive to increase its own price. By contrast, in a competitive setting, firms will resist such price increases, which increases would benefit their domestic competitors.

Hence, if the characterization of products as being 'like' or 'directly competitive or substitutable' is meant to refer only to the degree of substitutability between domestic and foreign products, it cannot be used as a sufficient proxy to determine whether differential taxation is likely to have adverse effects on imported products. Domestic products that are very 'like' imported products, but are sold in a competitive market, will enjoy a lower level of protection than less 'like' products sold by a domestic monopoly.

Thus, the effect of discriminatory treatment is a function of three factors: (i) the relative likeness or substitutability of the products, (ii) the relative competitiveness of the product market, and (iii) the magnitude of the tax differential.

\subsection{Likeness or substitutability: market definition}

This naturally raises the question of how to practically assess the effect of discriminatory treatment. Article III's reference to 'like' and 'directly competitive or substitutable products' emphasizes the degree of substitutability or differentiation as a relevant factor. This factor raises a tempting parallel with market definition in antitrust or competition law and indeed the Appellate Body occasionally refers to the 'relevant market'.

At the outset, it is worth spelling out the objective of market definition in antitrust. The formal definition of a relevant market for antitrust purposes (see e.g. the EU notice on market definition ${ }^{76}$ or the US horizontal merger guidelines ${ }^{77}$ ) is that of the narrowest set of products (including the products of the firm under investigation) in which a hypothetical monopolist could profitably increase price by $x \%$ (in which $x$ is often specified to be $5 \%$ or $10 \%$ ). This is known as the SSNIP test (small but significant nontransitory increase in price). Even if, in practice,

76 Commission notice on the definition of relevant market for the purposes of Community competition law [Official Journal C 372 of 9.12.1997].

77 US Department of Justice and the Federal Trade Commission, Horizontal Merger Guidelines, 19 August 2010, available at http://www.justice.gov/atr/public/guidelines/hmg-2010.html (last visited July 26, 2012). 
the delineation of a relevant market only rarely proceeds by directly estimating the profitability of a price increase over an alternative set of products, the SSNIP test is the organizing principle of market definition.

According to this principle, a relevant market is thus a set of products over which a firm with $100 \%$ market share (a hypothetical monopolist) could exercise market power (increase price) to a specified extent. Delineating a relevant market in this way thus acts as a way of calibrating market shares. Indeed, if a market share of $100 \%$ would imply a certain exercise of market power, market shares below that level can be interpreted relative to this benchmark. For instance, one could make the inference with some confidence that a market share of, say $50 \%$, in this relevant market will still confer an appreciable degree of market power to the firms concerned (given the presumption, supported by various models of competition and empirical evidence, that there is a positive link between market share and market power).

Of course, market share is only meant to be a first indicator of the market power that a firm may be able to exercise. Other factors are taken into account in order to interpret this market share, including the significance of capacity constraints, the extent to which the products controlled by the firm may be particularly close substitutes for one another, the existence of buyer market power, and the prospects for entry.

To recap, (i) the objective of market definition in an antitrust case is to evaluate the market power that a firm may be able to exercise either in its current form or in a particular counterfactual (for instance a merger), (ii) market definition in antitrust also includes an explicit tolerance level (typically, as mentioned above price rise of some $5 \%$ to $10 \%$ ) for the effect (market power) that it is meant to help evaluate, and (iii) market definition and the calculation of market shares only provide a first proxy for market power. Other factors are taken into account in order to interpret market power.

First, from this perspective, it is striking that the tools of market definition in antitrust cannot be directly transplanted for use in evaluation of the effect of discrimination in the context of Article III. With respect to the latter, the objective is not to assess market power but to assess the extent to which a set of products will benefit from the unfavourable treatment imposed on others (or alternatively, the extent to which a set of products will be harmed by this unfavourable treatment). It is only at a superficial level that the exercises are similar (arising from the observation that in both instances, the degree of substitution between products will matter). ${ }^{78}$

78 Note, however, that there is a direct parallel between the objective pursued under Article III and the objective of assessing the 'distortions of competition' induced by state aids under Article 107 of the Treaty of Rome (which instructs the Commission to identify to what extent competitors of the recipients of state support may be affected). 
Second, it is nonetheless instructive to observe that market definition in antitrust includes an explicit tolerance level with respect to market power. Such discipline is probably desirable as a matter of methodology. In the context of the assessment of discriminatory policies, this suggests that any methodology should formulate a benchmark in terms of the extent of discrimination and its effects. A natural candidate in this respect would be the difference in the (excise) tax between domestic and foreign products and the pass-through rate. In the same way that an increase in price (exercise of market power) of $x \%$ is considered to be a concern in antitrust, an increase in price for the domestic product of $x \%$ resulting from a differential tax of $y \%$ (of the initial price) and a pass-through rate of $z$ (with $x$ $=y \times z)$ could be considered a source of concern. This approach would thus allow for an explicit comparison of different measures involving different degrees of discrimination. For instance, a discriminatory tax of $2 \%$ with a pass-through rate of one-half could be compared with a discriminatory tax of $3 \%$ that has a passthrough rate of one-third (as both would yield a price increase of $1 \%$ ).

Third, in the same way that market power is an increasing function of market share, the pass-through rate is an increasing function of concentration. This suggests that market structure could initially be taken as given in evaluating the scope of products over which a certain pass-through rate would arise. Concretely, assume that a price increase of $x \%($ say $5 \%$ ) is considered to be tolerable and that the discriminatory tax is equal to $y \%$ (say $10 \%$ ) of the price, so that the tolerable pass-through is equal to $z=x / y$ (one half in our illustration). One could then ask what is the scope of products for which the pass-through rate is equal to $z$ (one half), assuming that the domestic market is a monopoly. Indeed, it may be easier to identify the pass-through rate, and hence the scope of the product that would benefit from a price increase of $5 \%$, when it is assumed that all domestic products are sold by a single firm. When this market is found, the extent to which competition in the domestic market would bring down the pass-through rate (and hence the effect of the discriminatory treatment) could then be assessed.

Note, however, that the definition of a relevant market in the counterfactual of a monopolist is possibly more compelling for antitrust purposes; the extent to which a monopolist would find it profitable to increase price (or alternatively would implement a profit-maximizing price of a certain percentage), is solely determined by the optimization of that firm and the demand conditions (the degree of substitution between the product sold by the hypothetical monopolist and the degree of substitution with alternative products). This makes the exercise particularly straightforward (at least at the level of principles). By contrast, the extent to which a hypothetical monopolist controlling domestic products would benefit from the increase in the marginal cost of foreign products involves the evaluation of an equilibrium response (it involves interactions between the foreign firms and the hypothetical monopolist). Hence, the exercise remains intricate and is possibly only marginally easier than a direct approach, in which the degree for pass-through is estimated for the observed competitive conditions. 


\subsection{The assessment of evidence by the Panel and Appellate Body}

In this section, we discuss how the Panel and Appellate Body have assessed the evidence on whether domestic and foreign spirits could be considered to be 'like' and 'directly competitive or substitutable'. We pay particular attention to the way in which the Panel and Appellate Body have dealt with quantitative evidence.

Before we discuss this evidence, a couple of remarks may be in order. First, it may be worth noticing that the finding of the Panel and Appellate Body that domestic and foreign spirits are like products is puzzling from the perspective of the extent of tax discrimination. Indeed, taxes on domestic products ( 14.68 pesos per proof litre) appear to be an order of magnitude (from 10 to 40 times) lower than taxes on imported spirits (from 159 to 635 pesos per proof litre). Such differences in taxes are likely to be reflected in substantial differences in consumer prices (with the prices of foreign spirits as a multiple of domestic items). In principle, such significant price differences are hard to square with the idea that like products are (according to the Appellate Body's own language) 'close to perfectly substitutable'. Indeed, if they were, all consumers would have shifted to the domestic items and imported products would have no sales.

As discussed above, the Appellate Body is concerned about the opposite inference; the Appellate Body argues that products do not appear to be substitutes for one another precisely because of the magnitude of the difference in tax, so that with lower taxes, they would be expected to compete more closely with one another. The intuition behind the Appellate Body's reasoning is clear, namely that if taxes on foreign products were lower, the market shares of the foreign products would be larger. However, the intuition is not robust. As mentioned above, the closer the substitution between the domestic and foreign products, the larger is the pass-through so that with a strong substitution and a large pass-through of taxes which are 10-40 times larger than those imposed on domestic products, the sales of foreign products should essentially have vanished.

The fact that sales of foreign products have not vanished in the face of such strong discrimination is more consistent with the view that the demand for foreign products is not strongly affected by the price of the domestic items (that the products are not close substitutes for one another). Hence, it appears that the reasoning of the Appellate Body is at best incomplete. In particular, the observation that sales have not vanished is difficult to reconcile with the idea that foreign and domestic products are close to perfectly substitutable. If they were, a price difference of a few percentage points would have brought the demand for foreign products to zero.

Our second preliminary remark concerns the evidence that can be used to assess the degree of substitution between products. As mentioned above, the cross-price elasticity of demand between products is the relevant concept to assess substitution (see also Horn and Mavroidis, 2004). In practice, cross-price elasticities may be difficult to estimate econometrically. Demand estimations have only recently 
become widespread in antitrust investigation and only for those products for which scanner or consumer-panel date are available. Besides the availability of data, these estimations face significant problems (for instance of endogeneity). However, there are numerous alternative pieces of evidence that may be telling and are often used in antitrust investigations. These include the use of natural experiment (like the introduction of new products, out-of-stock periods for particular products, or large discounts) as well as the analysis of price series (co-integration and correlation for instance). Marketing studies and consumer panels, as well as internal strategic documents, often also prove insightful.

The Panel discusses a couple of economic studies that have been submitted by the parties as part of its introductory remarks. ${ }^{79}$ These studies (one by Euromonitor International and another by a couple of academics, Abrenica and Ducanes, from the University of the Philippines) are described as attempting to assess the degree of substitution between domestic and foreign products. In the introductory section, the Panel only provides a short description of the studies and quotes some of its conclusions. In particular, the Panel reports that according to the Euromonitor study, with an import price decrease of $25 \%$ and domestic increase of $50 \%$, consumers would be ' $4.9 \%$ more willing to purchase imports and $4.0 \%$ less likely to purchase domestics'. The Abrenica and Ducanes study is reported as indicating that distilled spirits have low own- and cross-price elasticity and that local and imported brands are nonsubstitutable. The only conclusion drawn from the studies by the Panel (in the introductory section) is that 'despite their shortcomings, both studies suggest that, within the Philippines' market, a simultaneous increase in the price of domestic spirits and decrease in the price of imported spirits, such as that which would result from an equalization in the respective level of the excise tax, could result in the substitution of the consumption of imported spirits in lieu of domestic spirits' ${ }^{80}$

All this says is the demand for domestic and foreign spirits is not 'pathological' or in other words that it respects the regularity properties expected of any demand system, namely that demand will increase with the price of substitutes and decrease in own price. Surely, the Panel did not need the studies in order to reach that conclusion. One would have expected the Panel to draw some conclusion from the studies, not about the direction of the effects (the observation that the products are not complement), but about their magnitude of the effects (the extent to which the products are substitute).

The studies are further discussed by the Panel in its assessment of whether the products are 'like' and 'DCOS'. In the relevant sections, the Panel provides some information about the methodology of the studies. It appears that the Euromonitor study is based on an (online) survey and that the Abrenica and Ducanes study is

79 See Panel Report, Philippines-Spirits, section on factual aspects, paras. 2.31 to 2.45 . 80 Ibid., para. 2.45 . 
based on a conjoint analysis. ${ }^{81}$ The Panel also reveals that the studies have been criticized by the opposite parties but does not discuss the merit of these criticisms at any length. ${ }^{82}$ The Panel notes that neither of the studies is based on historical data on price and quantities (which it would regard as more reliable). The Panel then observes that the Euromonitor study is 'not an attempt to estimate and provide figures for the cross-price elasticity for imported.... and domestic... distilled spirits', and accordingly seems to attach little weight to the study. It is hard to tell whether the judgment of the Panel is appropriate without being told more about the methodology of the study.

With respect to the Abrenica and Ducanes study, the Panel observes that it estimates cross-price elasticities to be in the range of -0.01 to 0.07 . It is not clear whether this is a confidence interval or the result of different estimations (in which case, the first one would be puzzling). The Panel notes that these cross-price elasticities are regarded by the authors as low but does not offer its own view on the matter. In a footnote, the Panel seems to endorse some criticism put forward by the EU regarding this study (in particular regarding possible biases in the choices that respondents were confronted with and the econometric method used to infer the cross-price elasticities). ${ }^{83}$ But the footnote does not appear well placed, at the end of a sentence that discusses the price counterfactuals used for some of the conclusions.

Indeed, the Panel seems to be very concerned with the fact that neither of the two studies isolates the effect of a single price change (but rather compares scenarios in which both domestic and foreign prices change). This point is well taken since an increase in consumption for one product which follows a decrease in own price and an increase in the price of substitutes is consistent with the independent demand for the products. It is still a bit puzzling as presumably the conjoint analysis and regressions performed by Abrenica and Ducanes should in principle allow for the evaluation of the effects of single price changes. It should be merely a matter of interpretation of the coefficients.

Hence, the Panel does not provide a detailed discussion of the methodologies used by the studies and the weight that it attaches to their findings. What is even more surprising is then the Panel's conclusion ${ }^{84}$ that both 'studies support the proposition that there is a significant degree of competitiveness or substitutability in the Philippines's market between the distilled spirits at issue in the present dispute'. Importantly, the Panel's statement is no longer (as in the introductory section) about the fact that the products cannot be said not to be substitutes but explicitly about the 'significance' of that substitution. How the Panel can, in particular,

81 Ibid., para. 7.55 .

82 Ibid., paras. 7.53 and 7.110 .

83 Ibid., note 507.

84 Ibid., para. 7.113 . 
construe the Abrenica and Ducanes study as supporting the finding that there is a significant degree of substitution between domestic and foreign products, despite their own explicit conclusion to the contrary (whose validity is not explicitly denied by the Panel), is really unclear.

Overall, the level of transparency on the analysis performed by the Panel with respect to the economic studies is thus rather poor. This does not allow for proper accountability of the Panel.

\subsubsection{Likeness}

With respect to likeness, the Appellate Body seems to emphasize at various places that the core concept that would determine its assessment is the 'competitive relationship' between domestic and foreign products. For instance, in discussing the relevance of physical characteristics, the Appellate Body indicates that the Panel examines various criteria 'in order to make a determination about the nature and extent of a competitive relationship between and among the products'. The Appellate Body further notes that 'products that have very similar characteristics may not be like within the meaning of Art III:2 if their competitiveness or substitutability is low, while products that present certain physical differences may still be considered to be like if such physical differences have a limited impact on the competitive relationship between and among the products'. ${ }^{85}$

In discussing the relevance of the raw material used to make the products, the Appellate Body notes that if differences in raw materials 'leave fundamentally unchanged the competitive relationship among the final products, the existence of these differences would not necessarily negate a finding of "likeness" under Art III:2'.86 Further, in discussing the criteria used by Panels to establish 'likeness' under Art III:2, first sentence, the Appellate Body stresses that these criteria are not exhaustive and are the 'tools available to panels for organizing and assessing the evidence relating to the competitive relationship between and among the products'.87

It is not entirely clear, however, what is meant by the 'competitive relationship', which is sometimes distinguished from 'substitutability'. In the context of the framework discussed above, one possible interpretation is that a competitive relationship is simply meant to refer to demand substitution and hence the extent to which different products are close substitutes. According to this first interpretation, a competitive relationship would thus be determined only by the characteristics of consumer demand. Another interpretation is that a competitive relationship refers not only to consumer demand but also to competitive dynamics (and the fact that competitive relationship is sometimes distinguished from substitutability would 
support that interpretation). According to this latter interpretation, 'competitive relationship' would be determined by price responses so that products would be in a competitive relationship when a change in the price of one product prompts a strong response from the supplier of the other products. In terms of the framework discussed above, the competitive relationship would be a function of demand primitives but also of the conditions of competition. We would, of course, naturally favour such an interpretation, given that the protection granted by discriminatory treatment (or the foreclosure of foreign products) is affected by both factors.

Some additional findings by the Appellate Body may be worth discussing. First, the Appellate Body observes that consumer perceptions may be relevant for other dimensions than physical characteristics. The Appellate Body considered that 'while consumer perception of products is highly relevant to the overall determination of likeness under Art III:2, ... this element may reach beyond the products' properties, nature, and qualities, which concern the objective physical characteristics of the products'. ${ }^{88}$ Indeed, consumer preferences and their ultimate choices will be affected by other dimensions beyond the products' physical characteristics, such as its brand image. However, one would expect that brand image is precisely one of the main dimensions by which domestic and foreign spirits differ, which might indeed support the view that domestic and foreign spirits are not 'like'.

The Panel also discusses the argument that 'because of the difference in purchasing power of its population, the Philippine domestic market is segmented into two groups'. ${ }^{89}$ According to this argument, the poorer segment of the population would be unable to purchase the imported items. The Panel, however, insists that the argument would rest on evidence that there are two separate population groups with distinct consumption patterns. The Panel questions the plausibility of this, observing that 'the population in the Philippines does not appear to be divided into two separate groups, but is rather distributed along a continuum of income brackets'. This analysis is a bit puzzling.

First, it is clear that disposable income (the budget constraint faced by consumers) is a determinant of consumer choices; consumers with a tight budget constraint can be expected to be both more sensitive to the price of domestic items and less sensitive to the price of imported products (a decrease in the price of foreign products might not induce buyers to switch as they still prefer to buy the domestic item in light of their budget constraint).

Second, the pricing strategy of a domestic firm facing a distribution of income among potential buyers (and hence different own- and cross-price elasticities) depends very much on whether the domestic firm is able to engage in price discrimination. To illustrate, a domestic firm may find it profitable to charge low

88 Ibid., para. 132.

89 Panel Report, Philippines-Spirits, para. 7.59. 
prices for more price-elastic buyers (the less affluent) and high prices to others, for whom the imported items would be a realistic alternative. In such circumstances, the existence of a segment in which the foreign spirits are a realistic alternative and in which higher prices can be charged might be seen as evidence that, at least for some buyers, domestic firms benefit from the discriminatory taxes (more on this below). ${ }^{90}$ Third, in the absence of price discrimination, the domestic firm will have to charge a single price, which will be determined by the aggregate elasticity that it faces. The elasticity will, in turn, be determined by the distribution of consumers. If the majority of consumers are highly elastic, the aggregate elasticity will tend to reflect this, and the optimal price will tend to be low.

Hence, it would appear (i) that if price discrimination is feasible, the existence of different segments might indeed allow the domestic firms to benefit from the discriminatory tax and (ii) that the existence of just two identifiable customer groups is unimportant. What matters is whether price discrimination is feasible, and it may take place across more than two groups. If price discrimination is not feasible, the identification of different customer groups only matters insofar as they will determine the aggregate elasticity.

The Appellate Body's discussion of distribution channels should also be seen in this light. The Appellate Body supports the Panel in attaching little weight to the observation that distribution channels may be different for domestic and imported products and in particular that, unlike imported items, domestic products are also distributed off premises. This difference in distribution channels may be consistent with the view that price discrimination across channels is feasible and that there is a segment of buyers (those consuming spirits at home) for whom foreign spirits are not close substitutes for domestic products.

\subsubsection{Directly competitive or substitutable products}

The question of whether a possible segmentation of the domestic market for spirits may be relevant is further examined by the Appellate Body in its discussion of whether the products are DCOS. The Appellate Body acknowledges that large differences in price between domestic and foreign spirits could demonstrate that they belong to different segments. However, the Appellate Body, in support of the Panel, attaches weight to the finding that there is an overlap in the prices of imported and domestic distilled spirits. The Appellate Body also supported the Panel's finding that evidence of substitution in one segment supports the conclusion that imported and domestic spirits are capable of being substituted in the Philippines.

90 It is unclear from this perspective why the Philippines argued that there are different consumer groups. Its argument may have been that discrimination is not feasible and the weight of elastic consumers is such that the aggregate own-price elasticity of demand for domestic items is high and that the aggregate elasticity of demand for domestic items with respect to the price of foreign items is low. 
Evidence of overlapping prices between domestic and foreign products should be interpreted carefully. Even if the Appellate Body is not explicit about its analysis, it may suggest that there is a chain of substitution between different products so that some unbranded, low-quality domestic products are substitutes for higher-quality domestic products, which in turn are substitutes for low-quality imported products, themselves substitutes for higher-quality, branded imported items. The conclusion that products belong to the same relevant market because they are linked by a chain of substitution is a common fallacy in antitrust. Similarly, in the current framework, the existence of a chain of substitution may appear to be consistent with limited competitive interactions between the bulk of domestic and foreign products.

Regarding the segmentation, it is not clear why the 'capability' of being substituted is relevant in the absence of evidence that demand will indeed change over time in such a way that capability to substitute will turn into actual substitution. More generally, one can question the finding of the Appellate Body that the Panel did not have to focus on the most representative segment. This seems to suggest that in the presence of clear segmentation such that different prices apply in the different segments and such that for the largest segment of consumers there is no substitution between the domestic and foreign products, the Appellate Body would still be satisfied with evidence that there is a narrower segment in which domestic and foreign products are substitutes. This would seem questionable at least from the perspective of the assessment of the overall effects on domestic producers (since only a fraction of their sales would then be affected by the discriminatory taxes).

The Appellate Body explicitly considers the significance of the price counterfactual with which it is faced. It observes that taxes on foreign products are 10 to 40 times higher than those applied to domestic products and that actual competition with such differential taxes is probative of 'potential' competition, presumably if differences in taxes were lower. The term 'potential' competition may be a bit misleading here, in particular if reference is made to the antitrust practice, in which potential competition normally refers to entry. What the Appellate Body seems to have in mind here is rather the degree of 'competition' or substitution that would be observed in a different price counterfactual. However, as discussed above, the logic of the Appellate Body is not compelling; it seems to say that because products compete even under such high price differences, they will inevitably compete in a counterfactual in which prices are closer. As mentioned above, what is puzzling is rather that foreign products have any sales at all with such high price differences, if they are indeed such close substitutes to domestic products.

\section{Conclusion}

WTO jurisprudence relating to like products and DCOS products has tended to focus on a set of criteria derived from the Border Tax Adjustments case. These factors-physical characteristics, consumer preferences, end-uses, and tariff 
classification-are somewhat determinable through ordinary, as opposed to empirical economic, factual determination, although the tendency has been to use cross-price elasticity of demand as at least one way of suggesting consumer preferences. However, the Appellate Body has clearly and consistently stated that these factors are to be used to determine a single underlying question: whether products are in close enough competition to be 'like' or DCOS. Given that there is a more methodologically sophisticated, and more precise and plausible, way to determine the scope of competition, it is difficult to continue to justify using the less sophisticated and precise Border Tax Adjustment approach. Implicit in a more precise approach would be the establishment of benchmark degrees of competitiveness for determining like products and DCOS products, respectively.

We have suggested that any methodology for assessing discriminatory taxes should formulate a benchmark in terms of the extent of discrimination and its effects. A natural candidate in this respect would be the tax differential between domestic and foreign products and the pass-through rate. In the same way that market power is an increasing function of market share, the pass-through rate is an increasing function of concentration. This suggests that market structure could be taken as given in evaluating the scope of products over which a certain passthrough rate would arise. When this market is found, the extent to which competition in the domestic market would bring down the pass-through rate (and hence the effect of the discriminatory treatment) could be assessed.

However, a move toward a more sophisticated and precise approach to determining competition would definitively exclude from the determination of like products and DCOS products the question of the regulatory justification for differential treatment. It is entirely possible that products would be in very close competition, but would result in substantial consumption externalities, or even production externalities, that would make it perfectly rational, and desirable, to impose regulatory distinctions.

Therefore, either a new approach to interpretation, or a treaty amendment, would be appropriate to ensure that national measures that are justified in this way are not found to violate Article III of GATT. An interpretative approach would seem readily available that would include in the determination of 'so as to afford protection' in connection with the Second Sentence and 'less favourable treatment' in connection with Article III:4 the consideration of the nonprotectionist regulatory justification of the national measure. Indeed, in US-Clove Cigarettes, the Appellate Body, has interpreted 'less favourable treatment' within the context of Article 2.1 of the Agreement on Technical Barriers to Trade, to include an assessment of nonprotectionist regulatory justification. ${ }^{91}$

91 Appellate Body Report, United States-Measures Affecting the Production and Sale of Clove Cigarettes, WT/DS406/AB/R, adopted 24 April 2012, para. 182. 
However, there is no readily available textual 'hook' on which to hang this consideration in connection with First Sentence cases, and so it may be best to interpret 'like products' very narrowly in connection with First Sentence cases, focusing not just on competition but on the degree to which nonprotectionist regulatory rationales are implicated. 